\title{
DIFFERENTIAL LEUKOCYTE COUNTS IN “DOURADO”, Salminus maxillosus VALENCIENNES, 1840, FROM THE MOGI-GUAÇU RIVER, PIRASSUNUNGA, SP
}

\author{
RANZANI-PAIVA, M. J. T., ${ }^{1}$ RODRIGUES, E. L., ${ }^{2}$ VEIGA, M. L., ${ }^{2}$ \\ EIRAS, A. C. ${ }^{3}$ and CAMPOS, B. E. S. ${ }^{4}$ \\ ${ }^{1}$ Pesquisador Científico, Instituto de Pesca, Av. Francisco Matarazzo, 455, CEP 05001-900, \\ São Paulo, SP, Brazil \\ ${ }^{2}$ Laboratório de Impacto Ambiental e Histopatologia, Centro Universitário Adventista de São Paulo, \\ Estrada de Itapecerica, 5859, CEP 05858-001 \\ ${ }^{3}$ Estagiário, Instituto de Pesca \\ ${ }^{4}$ Pesquisador Científico, Instituto de Zootecnia, SAA, APTA, Nova Odessa, SP \\ Correspondence to: Maria José Tavares Ranzani-Paiva, Pesquisador Científico, Instituto de Pesca, Av. Francisco \\ Matarazzo, 455, CEP 05001-900, São Paulo, SP, Brazil, e-mail: mranzanipaiva@uol.com.br \\ Received January 14, 2002 - Accepted April 12, 2002 - Distributed August 31, 2003
}

(With 1 figure)

\begin{abstract}
From August, 1996 to December, 1997, 293 of “dourado" specimens, Salminus maxillosus (Valencienes, 1840), of various sizes, were caught in Mogi-Guaçu River, Emas Falls, for hematologic studies. Total weight (Wt in $\mathrm{g}$ ) and length ( $\mathrm{Lt}$ in $\mathrm{cm}$ ) were taken for each individual animal. Smears were prepared from blood samples and utilized for differential leukocyte counts (lymphocytes, neutrophils, monocytes, eosinophils, special granulocytic cell and immature cells). The mean percentages of leukocytes were determined according to sex and stage of gonadal maturation (immature, in maturation, mature, spent and resting). Significant differences between male and female occurred only for the special granulocytic cell. In analyzing the leukocyte profile during gonadal development, only female showed significant differences in mean percentages of lymphocytes, neutrophils, monocytes and eosinophils.
\end{abstract}

Key words: “dourado", Salminus maxillosus, leukocytes, hematology.

\section{RESUMO}

\section{Contagem diferencial de leucócitos em dourado, Salminus maxillosus VALENCIENNES, 1840, no rio Mogi-Guaçu, Pirassununga, SP}

No período de agosto de 1996 a dezembro de 1997, foram capturados 293 exemplares de dourado, S. maxillosus (Valencienes, 1840), de vários tamanhos, no Rio Mogi-Guaçu, Cachoeira das Emas, para estudos hematológicos. De cada indivíduo foram tomados os dados de peso total (Wt - em gramas) e comprimento total $(\mathrm{Lt}-\mathrm{em} \mathrm{cm})$. Com as amostras de sangue foram confeccionadas extensões utilizadas na identificação e contagem diferencial de leucócitos (linfócitos, neutrófilos, monócitos, eosinófilos, células granulocíticas especiais e células imaturas). As médias das porcentagens de leucócitos foram analisadas por sexo e por estádio de maturação gonadal (imaturo, em maturação, maduro, esgotado e repouso). Apenas para as células granulocíticas especiais foram encontradas diferenças significativas entre machos e fêmeas. Na análise por estádio de desenvolvimento gonadal somente as fêmeas apresentaram diferenças significativas entre as porcentagens médias dos linfócitos, neutrófilos, monócitos e eosinófilos.

Palavras-chave: dourado, Salminus maxillosus, leucócitos, hematologia. 


\section{INTRODUCTION}

Detailed comparative studies in human and domestic animals have delineated conditions to show that blood is the only "mirror" in which vital processes occurring in organisms are reflected (Srivastava, 1969). Blood cells represent a free, connective tissuetype cell, which neither maintain intimate connections with other cells, nor possess intercellular substances, constituting the homeostatic force of the organism (Kalashnikova, 1976). Hematopoietic tissues produce and subsequently release them into the plasma bloodstream, in wich they are suspended. The factors that determine and maintain the characteristic forms of the blood cells are the specific molecular constituents of the membrane structures and colloid, where a provoked alteration in any of these constituents may be responsible for atypical cells, permitting an early diagnosis of a possible pathology (Cormack, 1991).

When hematologic values are considered, one must realize that these reflect the response of organism and should be regarded in comparison with normal values for that species, as related by Quentel \& Obach (1992). With normal limits of variation it is possible to correlate internal changes, establishing levels for a well-being state for organisms.

The determination of normal blood values must take into account also some biological information, because hematologic tissues undergo variation as a result of endogenous conditions (Pitombeira, 1972; Kavamoto et al., 1983, 1985; Sarasquete, 1984; Ranzani-Paiva \& Godinho, 1983; Ranzani-Paiva, 1991, 1995, 1996; Ranzani-Paiva \& Eiras, 1992; Rambhaskar \& Rao, 1987). Nonetheless, the influence of environmental variation on the hematologic picture has demonstrated that exogenous factors such as temperature, pressure, salinity, $\mathrm{pH}$, and dissolved $\mathrm{O}_{2}$, among others, can alter blood values (Mahajan \& Dheer, 1979). This variation in blood composition is observed, not only among different species, but also in individuals of the same species or even in a single individual, depending on the environmental and physiological conditions to which fish are subjected (Kalashnikova, 1976).

In this work, the organism elected for study was $S$. maxillosus, commonly known as "dourado", Characidae, is one of the most important species from both a commercial and ecological point of view in the regions in which they live. The aim was to study the possible alterations in differential leukocyte counts of Salminus maxillosus, in Mogi-Guaçu River, Emas Falls, located at Pirassununga, SP, in relation to sex and stage of gonadal maturation.

\section{MATERIAL AND METHODS}

During the period of August, 1996 to December, 1997, about 20 specimens of "dourado", $S$. maxillosus, of various sizes were caught monthly in Mogi-Guaçu River, in stretches above and below the barrier, of Emas Falls (21 ${ }^{\circ} 58^{\prime} \mathrm{S}$ $47^{\circ} 26^{\prime} \mathrm{W}$, altitude of $560 \mathrm{~m}$ ), at Pirassununga, SP. The catch was carried out utilizing different forms of fishing gear (fishhook, fishing net and trawling net).

After the catch, fishes were transported to the Biology of Fluvial Fishes Laboratory "Dr. Pedro de Azevedo", Fishery Institute, Pirassununga. They were stored in asbestos-cement boxes with a capacity of 1000 liters, filled with water continuously aerated through a compressor, for a period of two hours.

Blood samples were withdraw by caudal puncture with help of disposable syringes lightly moistened with a diluted heparin solution and utilized for the identification and differential leukocyte counting performed with blood smears stained with May-Grünwald-Giemsa according to Rosenfeld (1947). The smears were examined by light microscopy using an oil immersion objective.

After the collection of the blood sample, the fish was stunned, weighed (total weight in $\mathrm{g}$ ) and measured (total length in $\mathrm{cm}$ ). The sex and stage of gonadal development was determined by macroscopic inspection of the gonads, according to Barbieri et al. (2001) The following stages were recognized: immature (I); maturation (II); mature (III); spent (IV) and resting (V).

The means and standard deviation for each leukocyte percentage were calculated for each individual considering sex and stage of gonadal maturation. The computational program LSMLMW (Harvey, 1987) was utilized to determine the influence of some biological effects on the percentage of leukocytes, whereby analyses were 
performed by the method of least squares, as a result of unequal numbers of repetitions of the subclasses studied.

\section{RESULTS AND DISCUSSION}

In this study 293 specimens of S. maxillosus were analyzed, being 113 male (total length varying 37.5 to $73.5 \mathrm{~cm}$ and a total weight of 540 to 4,400 $\mathrm{g}$ ) and 180 female (total length varying 35.6 to 73.5 $\mathrm{cm}$ and a total weight of 480 to $7,030 \mathrm{~g}$ ).

The Fig. 1 shows the different cells identified in blood smears of S. maxillosus. 1) Erythrocytes: elliptical cells with a central nucleus generally following the shape of cell; they have a compact chromatin and acidophilic cytoplasm which occupies most of cell. 2) Thrombocytes: possess various shapes (round, oval or fusiform), with large nuclei which follow the contour of cell and sparse cytoplasm weakly staining with eosin. They generally are found to be key agents in the process of coagulation (Casillas \& Smith, 1977), in addition as a part of the inflammatory process (Matushima \& Mariano, 1996). 3) Lymphocytes: often small cells; but it is possible to find some large lymphocytes. Their nucleus occupy most of the cell and chromatin is compact and homogeneous, and cell contains a paucity of basophilic-staining cytoplasm. 4) Neutrophils: round cells with an eccentric nucleus that can vary in shape from round to segmented, with the chromatin slightly compact; the cytoplasm is abundant and is lightly stained by eosin with observable fine clumps. 5) Monocytes: large cells of varying shape having also a large nucleus, occupying about two-thirds of the cell; the cytoplasm appears discreetly basophilic, vacuolized and lacking granuoles. Monocytes can phagocytize circulating bacteria and viruses and are immediate precursors of macrophages, when they migrate to areas of acute inflammation with an enormous capacity for phagocytosis. 6) Eosinophils: round shape, and normally the nucleus is eccentric and the cytoplasm keeps large eosinophilic granules. 7) Special granulocytic cells: similar in size to neutrophils; however, nucleus is eccentric and chromatin is very dense, the cytoplasm shows granules that in some cells are not stained by acidic or basic dyes. The last cells show cytochemical properties similar to those of neutrophils and were therefore designated by Veiga et al. (2000) as type II neutrophils. 8) Immature cells: have a slightly round shape, with a large nucleus occupying almost all the cell and chromatin distributed in fine clumps, and the cytoplasm is intensely stained by hematoxylin.

The most abundant cells in the peripheral blood of $S$. maxillosus were lymphocytes and neutrophils (Table 1), which was also demonstrated in Pimelodus maculatus (Ribeiro, 1978), Synbranchus marmoratus (Nakamoto et al., 1991), Mugil platanus (RanzaniPaiva, 1995), and Oncorhynchus mykiss (RanzaniPaiva et al., 1998).

According to statistical analysis presented in Table 1, a significant difference occurred only between the mean percentage of male and female the special granulocitic cell (SGC). The other cell types did not show differences between sexes.

Table $2 \mathrm{a}$ and $2 \mathrm{~b}$ shows the mean differential leukocyte counts according to gonadal maturation stage. Through analyses of variance it was found that the percentage of different leukocytes in male did not show significant variation $(p>0.05)$. However, a marked variation was determined in female between stages for lymphocytes, neutrophils, monocytes and eosinophils $(\mathrm{p}<0.05)$. No significant difference among stages could be found for other cell types (SGC and immature cells).

It is clearly evident that female increased percentage of immature cells in stage I. This probably occurs due to the needs of the organism for attaining maturity. Thus, the hematopoietic tissues must release into circulation still immature cells with greater intensity.

Pickering (1986), studying Salmo trutta, observed a reduction in the number of lymphocytes in mature specimens of both sexes, which did not occur in Salminus maxillosus, but on the opposite it showed an increased percentage of lymphocytes in mature female. This author even correlated the decrease in lymphocytes with inter-renal activity and suggested that a biological consequence of lymphopenia could be related to the fish capacity when trying to defend itself against pathogens. Thus, sexual maturation of Salmo trutta is accompanied by susceptibility to disease. 

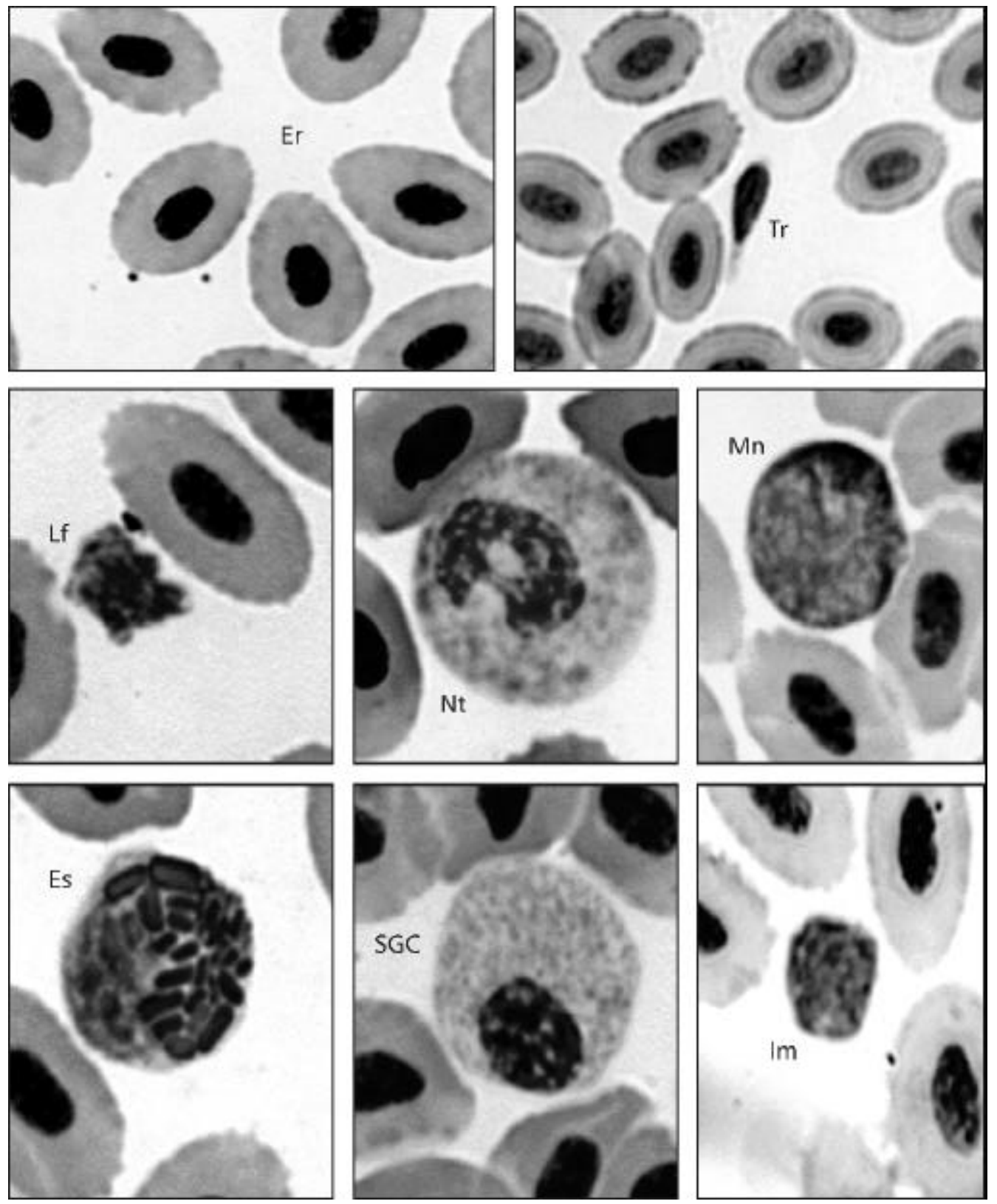

Fig. 1 - Blood cells of S. maxillosus from Mogi-Guaçu River, Emas Falls, Pirassununga, SP. Erithocyte (Er), thrombocyte (Tr), limphocyte (Lf), neutrophil (Nt), monocyte (Mn), eosinophil (Es), special granulocytic cell (SGC), and imature cell (Im) $(1000 \mathrm{x})$. 


\section{TABLE 1}

Variation rates $(\mathrm{Ax})$, mean values $(\overline{\mathrm{X}})$ and standard deviation $(\mathrm{S} \overline{\mathrm{X}})$ of the percentage values of limphocytes (Lf), neutrophils (Nt), monocytes, (Mn), eosinophils (Es), specials granulocytic cells (SGC) and imature cells (Im) of $S$. maxillosus from Mogi-Guaçu River, Pirassununga, SP, analysed by sex.

\begin{tabular}{|c|c|c|c|c|c|}
\hline Leucócitos & Sexo & $\begin{array}{c}\mathbf{A x} \\
(\text { menor }- \text { maior })\end{array}$ & $\overline{\mathrm{X}}$ & $S \bar{x}$ & $\mathbf{N}$ \\
\hline \multirow[t]{3}{*}{$\operatorname{Lf}(\%)$} & $\mathrm{M}$ & $12.8-94.1$ & $57.3 \mathbf{a}$ & 2.03 & 113 \\
\hline & $\mathrm{F}$ & $2.5-93.6$ & $50.3 \mathrm{a}$ & 1.9 & 180 \\
\hline & Total & $2.5-94.1$ & 53.1 & 1.4 & 293 \\
\hline \multirow[t]{3}{*}{$\mathrm{Nt}(\%)$} & $M$ & $0.8-78.8$ & $28.2 \mathbf{a}$ & 1.9 & 113 \\
\hline & $\mathrm{F}$ & $1.1-83.7$ & $36.5 \mathrm{a}$ & 1.7 & 180 \\
\hline & Total & $0.8-83.7$ & 33.3 & 1.3 & 293 \\
\hline \multirow[t]{3}{*}{$\mathrm{Mn}(\%)$} & $\mathrm{M}$ & $0.0-39.2$ & $5.0 \mathrm{a}$ & 0.6 & 113 \\
\hline & $\mathrm{F}$ & $0.0-52.0$ & $6.3 \mathrm{a}$ & 0.5 & 180 \\
\hline & Total & $0.0-52.0$ & 5.8 & 0.4 & 293 \\
\hline \multirow[t]{3}{*}{ Es $(\%)$} & $\mathrm{M}$ & $0.0-19.5$ & $2.4 \mathbf{a}$ & 0.2 & 113 \\
\hline & $\mathrm{F}$ & $0.0-11.7$ & $2.1 \mathrm{a}$ & 0.2 & 180 \\
\hline & Total & $0.0-19.5$ & 2.2 & 0.1 & 293 \\
\hline \multirow[t]{3}{*}{ SGC (\%) } & $\mathrm{M}$ & $0.0-31.0$ & $4.3 \mathrm{a}$ & 0.5 & 113 \\
\hline & $\mathrm{F}$ & $0.0-26.3$ & $2.3 \mathbf{b}$ & 0.3 & 180 \\
\hline & Total & $0.0-31.0$ & 3.0 & 0.2 & 293 \\
\hline \multirow[t]{3}{*}{$\operatorname{Im}(\%)$} & $\mathrm{M}$ & $0.0-15.0$ & $2.6 \mathrm{a}$ & 0.3 & 113 \\
\hline & $\mathrm{F}$ & $0.0-15.7$ & $2.4 \mathbf{a}$ & 0.2 & 180 \\
\hline & Total & $0.0-15.7$ & 2.5 & 0.2 & 293 \\
\hline
\end{tabular}

$\mathrm{N}=$ number of fishes.

Means followed by same letter $(\mathrm{p}<0.01)$.

In relation to neutrophils, the results obtained in this work agree with those of Cavicchioli \& Zavarini (1977), who demonstrated in Coregonus macrophthalmus female a decrease in neutrophil levels during spawning, with the opposite happing in male. This change is also possible due to fish sensitivity to variation in temperature, more than to a compensatory immune mechanism (Quentel \& Obach, 1992). Increases in neutrophil percentage is generally associated with some pathology in fish, as reported for an infection by Ichithyophthirius multifilis (Hines \& Spira, 1973), a viral infection in Oncorhynchus nerka (Watson et al., 1956), an infection by digenetic parasites in Channa punctatus (Mahajan \& Dheer, 1979), and an infection by ectoparasites during the reproductive period in adult specimens of Salmo trutta
(Pickering, 1986). When the percentages of leukocytes are analyzed in relation to the biological data of total weight and total length (Table 3), it is noted that the "r" values are rather low with shows that these percentages do not change with fish growning.

\section{CONCLUSIONS}

The analysis of hematologic parameters in relation to the biology of "dourado", S. maxillosus, allows us to conclude: 1) The detected variation did not show a correlation with sex. 2) The stage of gonadal development is responsible for the changes in some leukocyte percentages in the peripheral blood of female. 3) The total length factor of individual animals did not influence the hematologic variables. 
Variation rates $(\mathrm{Ax})$, mean values $(\overline{\mathrm{X}})$ and standard deviation $(\mathrm{S} \overline{\mathrm{X}})$ of the percentage values of limphocytes (Lf), neutrophils (Nt) and monocytes (Mn) of S. maxillosus from Mogi-Guaçu River, Pirassununga, SP, analysed by gonadal maturation stages.

\begin{tabular}{|c|c|c|c|c|c|c|c|c|c|c|c|c|c|}
\hline \multirow{2}{*}{ Sex } & \multirow{2}{*}{ Stage } & \multicolumn{4}{|c|}{ Lf } & \multicolumn{4}{|c|}{ Nt } & \multicolumn{4}{|c|}{ Mn } \\
\hline & & $\mathbf{n}$ & $\mathbf{A x}$ & $\overline{\mathbf{X}}$ & $\mathbf{S} \overline{\mathbf{x}}$ & n & $\mathbf{A x}$ & $\overline{\mathbf{X}}$ & $\mathbf{S} \overline{\mathbf{x}}$ & $\mathbf{n}$ & $\mathbf{A x}$ & $\overline{\mathbf{X}}$ & $\mathbf{S} \overline{\mathbf{x}}$ \\
\hline & I & 27 & $12.8-92.2$ & 63.23 & 4.51 & 27 & $0.8-78.8$ & 23.63 & 4.51 & 27 & $0.0-12.1$ & 2.99 & 0.64 \\
\hline \multirow[t]{2}{*}{$\sigma$} & III & 22 & $17.7-73.2$ & 48.45 & 3.61 & 22 & $12.5-72.1$ & 34.10 & 3.41 & 22 & $0.0-39.2$ & 7.66 & 1.78 \\
\hline & IV & 7 & $29.7-81.3$ & 54.41 & 8.16 & 7 & $7.2-56.7$ & 27.23 & 6.26 & 7 & $1.0-15.8$ & 5.59 & 1.99 \\
\hline \multirow[t]{3}{*}{$\mathbf{P}$} & & & & $>0.05$ & & & & $>0.05$ & & & & $>0.05$ & \\
\hline & I & 4 & $13.9-82.2$ & 34.60 & 15.97 & 4 & $9.1-69.3$ & 48.33 & 14.12 & 4 & $1.4-22.2$ & 8.25 & 4.84 \\
\hline & II & 79 & $2.5-93.6$ & 42.35 & 2.69 & 79 & $2.1-83.7$ & 44.44 & 2.47 & 79 & $0.0-37.6$ & 8.06 & 0.84 \\
\hline \multirow[t]{2}{*}{$Q$} & III & 7 & $41.3-87.0$ & 74.59 & 5.86 & 7 & $1.9-45.3$ & 12.47 & 5.59 & 7 & $1.3-4.8$ & 2.71 & 0.62 \\
\hline & IV & 12 & $4.0-92.3$ & 62.89 & 8.74 & 12 & $1.1-69.1$ & 21.38 & 6.08 & 12 & $0.0-52.0$ & 7.88 & 4.17 \\
\hline
\end{tabular}

$\mathrm{p}>0.05 . *$ significant; $* *$ extremely significant. 
TABLE 2B

Variation rates $(\mathrm{Ax})$, mean values $(\overline{\mathrm{X}})$ and standard deviation $(\mathrm{S} \overline{\mathrm{X}})$ of the percentage values of eosinophils (Es), speciais granulocytic cells (SGC) and imature cells (Im) of $S$. maxillosus from Mogi-Guaçu River, Pirassununga, SP, analysed by gonadal maturation stages.

\begin{tabular}{|c|c|c|c|c|c|c|c|c|c|c|c|c|c|}
\hline \multirow{2}{*}{ Sex } & \multirow{2}{*}{ Stage } & \multicolumn{4}{|c|}{ Es } & \multicolumn{4}{|c|}{ CGE } & \multicolumn{4}{|c|}{ Im } \\
\hline & & $\mathbf{n}$ & $\mathbf{A x}$ & $\overline{\mathbf{X}}$ & $\mathbf{S} \overline{\mathbf{x}}$ & $\mathbf{n}$ & $\mathbf{A x}$ & $\overline{\mathbf{X}}$ & $\mathbf{S} \overline{\mathbf{x}}$ & $\mathbf{n}$ & $\mathbf{A x}$ & $\overline{\mathbf{X}}$ & $\mathbf{S} \overline{\mathbf{x}}$ \\
\hline & I & 27 & $0.0-5.9$ & 2.17 & 0.29 & 27 & $0.0-19.5$ & 5.84 & 0.91 & 27 & $0.0-10.0$ & 2.14 & 0.58 \\
\hline & II & 21 & $0.0-5.0$ & 1.92 & 0.46 & 21 & $0.0-31.0$ & 3.49 & 1.42 & 21 & $0.0-10.0$ & 2.02 & 0.62 \\
\hline \multirow[t]{3}{*}{$\sigma$} & III & 22 & $0.4-5.0$ & 2.43 & 0.30 & 22 & $0.0-15.4$ & 3.03 & 0.86 & 22 & $0.0-13.5$ & 4.29 & 0.83 \\
\hline & IV & 7 & $0.4-10.0$ & 3.80 & 1.40 & 7 & $1.5-10.0$ & 5.81 & 1.08 & 7 & $0.0-15.0$ & 3.17 & 2.08 \\
\hline & V & 36 & $0.0-19.5$ & 2.70 & 0.60 & 36 & $0.0-23.2$ & 4.00 & 1.00 & 36 & $0.0-9.0$ & 2.04 & 0.41 \\
\hline \multirow[t]{3}{*}{$\mathbf{P}$} & & & & $>0.05$ & & & & $>0.05$ & & & & $>0.05$ & \\
\hline & I & 4 & $0.0-3.0$ & 0.75 & 0.75 & 4 & $0.0-5.8$ & 2.70 & 1.22 & 4 & $1.4-15.7$ & 5.63 & 3.41 \\
\hline & II & 79 & $0.0-9.1$ & 1.16 & 0.19 & 79 & $0.0-17.0$ & 1.95 & 0.35 & 79 & $0.0-9.9$ & 2.02 & 0.29 \\
\hline \multirow[t]{3}{*}{$\phi$} & III & 7 & $0.8-11.7$ & 5.59 & 1.50 & 7 & $0.4-6.5$ & 2.19 & 0.78 & 7 & $0.0-6.1$ & 2.46 & 0.94 \\
\hline & IV & 12 & $0.4-4.1$ & 3.15 & 0.32 & 12 & $0.0-13.6$ & 2.23 & 1.08 & 12 & $0.0-8.9$ & 2.42 & 0.90 \\
\hline & $\mathrm{V}$ & 78 & $0.0-9.7$ & 2.60 & 0.27 & 78 & $0.0-26.3$ & 2.61 & 0.50 & 78 & $0.0-13.0$ & 2.65 & 0.34 \\
\hline $\mathbf{P}$ & & & & $<0.05 * *$ & & & & $>0.05$ & & & & $>0.05$ & \\
\hline
\end{tabular}

$\mathrm{p}>0.05$. ** extremely significant. 
TABELA 3

Correlation matrix of the leukocytes percentage of $S$. maxillosus from Mogi-Guaçu River, Emas Falls, Pirassununga, SP

\begin{tabular}{|c|c|c|c|c|c|c|c|c|}
\hline & Lt (cm) & Wt (g) & Lf (\%) & Nt (\%) & Mn (\%) & Es (\%) & SGC (\%) & Im (\%) \\
\hline Lt (cm) & 1.00 & 0.95 & -0.08 & 0.14 & 0.05 & 0.04 & -0.34 & -0.02 \\
\hline Wt (g) & 0.95 & 1.00 & -0.08 & 0.13 & 0.07 & 0.04 & -0.32 & -0.02 \\
\hline
\end{tabular}

$\mathrm{Lt}=$ total lenght $; \mathrm{Wt}=$ total weigth $; \mathrm{Lf}=$ limphocyte $; \mathrm{Nt}=$ neutrophil $; \mathrm{Mn}=$ monocyte $;$ Es = eosinophil; $\mathrm{SGC}=$ special granulocytic cell; $\mathrm{Im}=$ imature cell.

\section{REFERENCES}

BARBIERI, G., SALLES, F. A. \& CESTAROLLI, M. A., 2001, Reproductive and nutritional dynamics of Salminus maxillosus Valenciennes (Pisces, Characidae) at Mogi-Guaçu River. São Paulo, Brazil. Acta Scientiarum, 23(2): 441-444.

CASILLAS, E. \& SMITH, L. S., 1977, Effect of stress on blood coagulation and haematology in rainbow trout (Salmo gairdneri). J. Fish Biol., 10(5): 481-491.

CAVICCHIOLI, G. \& ZAVARINI, A., 1977, Observations on the morphology and seasonal variations of blood cells in the whitefish bondella, Coregonus macrophthalmus Nussl.(?) of lake Maggiore (North Italy). Monitore Zool. Ital., 11: 173-182.

CORMACK, D. H., 1991, Histologia. Guanabara Koogan, Rio de Janeiro, 9 ed., p. 151.

HARVEY, W. R., 1987, User's guide for LSMLMW: mixed model version. Ohio State University, 59p.

HINES, R. \& SPIRA, D. T., 1973, Ichyophthiriasis in the mirror carp. III Leucocyte response. J. Fish Biol., 5: 527-534.

KALASHNIKOVA, Z. M., 1976, On the classification of morphological elements in the blood of fish. J. Ichthy., 3(16): 459-472.

KAVAMOTO, E. T., TOKUMARU, M., SOUZA-SILVA, R. A. P. \& CAMPOS, B. E. S., 1985, Variações morfológicas e contagem diferencial das células leucocitárias de "cascudo", Plecostomus albopunctatus (Regan, 1908) em relação ao desenvolvimento gonadal. B. Inst. Pesca, 12(2): 15-23.

KAVAMOTO, E. T., RANZANI-PAIVA, M. J. T. \& TOKUMARU, M., 1983, Estudos hematológicos em "bagre", Rhamdia hilarii (Val. 1840), Teleósteo, no estádio de desenvolvimento gonadal maduro. B. Inst. Pesca, 10 (único): 53-60.

MAHAJAN, C. L. \& DHEER, J. C., 1979, Cell types in the peripheral blood of an air-breathing fish Channa punctatus. J. Fish Biol., 14: 481-487.

MATUSHIMA, E. R. \& MARIANO, M., 1996, Kinetics of the inflammatory reaction induced by carrageenin in the swimbladder of Oreochromis niloticus (Nile tilapia). Braz. J. Vet. Res. Anim. Sci., 33(1): 5-10.
NAKAMOTO, W., SILVA, A. J., MACHADO, P. E. A. \& PADOVANI, C. R., 1991, Glóbulos brancos e Cyrilia gomesi (hemoparasita) em Synbranchus marmoratus Bloch, 1795 (Pisces; Synbranchidae) da região de Birigüi, SP. Rev. Brasil. Biol., 51(4): 755-761.

PICKERING, A. D., 1986, Changes in blood cell composition of the brown trout, Salmo trutta L., during the spawning season. J. Fish Biol., 29(3): 335-347.

PITOMBEIRA, M. S., 1972, Hematologia do apaiari, Astronotus ocellatus (Cuvier, 1829). Peixes teleósteos. Aspectos morfológicos e fisiológicos. São Paulo, SP. Doctoral Thesis, Instituto de Biociências, Depto. de Fisiologia Geral, Universidade de São Paulo and Universidade Federal do Ceará, 133p.

QUENTEL, C. \& OBACH, A., 1992, The cellular composition of the blood and haematopoietic organs of turbot Scophthalmus maximus L. J. Fish Biol., 41: 709-716.

RAMBHASKAR, B. \& RAO, K. S., 1987, Comparative haematology of ten species of marine fish from Visakhapatnam Coast. J. Fish Biol., 30(1): 59-66.

RANZANI-PAIVA, M. J. T., 1991, Hematologia dos peixes. In: H. S. L. Santos (ed.), Histologia de peixes. Unesp, Jaboticabal, pp. 65-70.

RANZANI-PAIVA, M. J. T., 1995, Células sangüíneas e contagem diferencial dos leucócitos de tainha, Mugil platanus Günther, 1880 (Osteichthyes, Mugilidae) da região estuarinolagunar de Cananéia, SP (Lat. $25^{\circ} 00^{\prime} \mathrm{S}$ - Long. $47^{\circ} 55^{\prime} \mathrm{W}$ ). Bol. Inst. Pesca, 22(1): 23-40.

RANZANI-PAIVA, M. J. T., 1996, Células sangüíneas e contagem diferencial dos leucócitos em pirapitinga do sul, Brycon sp., sob condições experimentais de criação intensiva. Revista Ceres, 43(250): 685-696.

RANZANI-PAIVA, M. J. T. \& EIRAS, A. C., 1992, Células sangüíneas e contagem diferencial dos leucócitos de 13 espécies de teleósteos do rio Paraná, PR. In: SIMBRAq, 7, EMBRAPA, 2, Peruíbe, SP. Anais... pp. 173-181.

RANZANI-PAIVA, M. J. T. \& GODINHO, H. M., 1983, Sobre células sanguíneas e contagem diferencial de leucócitos e eritroblastos em curimbatá, Prochilodus scrofa Steindachner, 1881 (Osteichthyes, Cypriniformes, Prochilodontidae). Rev. Brasil. Biol., 43(4): 331-338. 
RANZANI-PAIVA, M. J. T., TABATA, Y. A. \& EIRAS, A. C., 1998, Hematologia comparada entre diplóides e triplóides de truta arco-íris, Oncorhynchus mykiss Walbaum (Pisces, Salmonidae). Revta. Bras. Zool., 5(4): 1093-1102.

RIBEIRO, W. R., 1978, Contribuição ao estudo de hematologia de peixes. Morfologia e citoquímica das células do sangue e dos tecidos hematopoiéticos do mandi amarelo, Pimelodus maculatus Lacèpéde, 1803. Ribeirão Preto, Doctoral Thesis, Faculdade de Medicina de Ribeirão Preto, Universidade de São Paulo, 140p.

ROSENFELD, G., 1947, Corante pancrômico para hematologia e citologia clínica. Nova combinação dos componentes do May-Grünwald e do Giemsa num só corante de emprego rápido. Mem. Inst. Butantan, 20: 329-334.

SARASQUETE, M. C., 1984, Variación anual de parámetros hematológicos del pez sapo marino, Halobatrachus didactylus. S. Inv. Pesq., 48(3): 399-417.
SRIVASTAVA, A. K., 1969, Leucocytes in the blood of four freshwater teleosts. Amer. Zool., 9: 1149.

VEIGA, M. L., EGAMI, M. I., RANZANI-PAIVA, M. J. T. \& RODRIGUES, E. L., 2000, Aspectos morfológicos y citoquímicos de las células sanguíneas de Salminus maxillosus Valenciennes, 1840 (Characiformes, Characidae). Rev. Chil. Anat., 18(2): 245-250.

WATSON, M. E., GUENTER, R. W. \& ROYCE, R. D., 1956, Hematology of healthy and virus-diseased sockeye salmon, Oncorhynchus nerka. Zoologica, 41(1): 27-37. 